\title{
Characterization of a Carbonyl Reductase from Rhodococcus erythropolis WZ010 and Its Variant Y54F for Asymmetric Synthesis of (S)-N-Boc-3-Hydroxypiperidine
}

\author{
Xiangxian Ying ${ }^{1, *}$, Jie Zhang ${ }^{1}$, Can Wang ${ }^{1}$, Meijuan Huang ${ }^{1}$, Yuting $\mathrm{Ji}^{1}{ }^{1}$, Feng Cheng ${ }^{1}$, \\ Meilan $\mathrm{Yu}^{2}$, Zhao Wang ${ }^{1}$ and Meirong Ying ${ }^{3, *}$ \\ 1 Key Laboratory of Bioorganic Synthesis of Zhejiang Province, College of Biotechnology and Bioengineering, \\ Zhejiang University of Technology, Hangzhou 310014, China; m15958047548@163.com (J.Z.); \\ m17816035735@163.com (C.W.); meyroline.huang@gmail.com (M.H.); LJ15957189939@163.com (Y.J.); \\ fengcheng@zjut.edu.cn (F.C.); hzwangzhao@163.com (Z.W.) \\ 2 College of Life Sciences, Zhejiang Sci-Tech Univeristy, Hangzhou 310018, China; meilanyu@zstu.edu.cn \\ 3 Grain and Oil Products Quality Inspection Center of Zhejiang Province, Hangzhou 310012, China \\ * Correspondence: yingxx@zjut.edu.cn (X.Y.); hz85672100@163.com (M.Y.); Tel.: +86-571-88320781 (X.Y.)
}

Academic Editor: Stefano Serra

Received: 11 November 2018; Accepted: 27 November 2018; Published: 28 November 2018

\begin{abstract}
The recombinant carbonyl reductase from Rhodococcus erythropolis WZ010 (ReCR) demonstrated strict (S)-stereoselectivity and catalyzed the irreversible reduction of $\mathrm{N}$-Boc-3piperidone (NBPO) to (S)-N-Boc-3-hydroxypiperidine [(S)-NBHP], a key chiral intermediate in the synthesis of ibrutinib. The $\mathrm{NAD}(\mathrm{H})$-specific enzyme was active within broad ranges of $\mathrm{pH}$ and temperature and had remarkable activity in the presence of higher concentration of organic solvents. The amino acid residue at position 54 was critical for the activity and the substitution of Tyr54 to Phe significantly enhanced the catalytic efficiency of ReCR. The $k_{\text {cat }} / K_{\mathrm{m}}$ values of ReCR Y54F for NBPO, $(R / S)$-2-octanol, and 2-propanol were $49.17 \mathrm{~s}^{-1} \mathrm{mM}^{-1}, 56.56 \mathrm{~s}^{-1} \mathrm{mM}^{-1}$, and $20.69 \mathrm{~s}^{-1} \mathrm{mM}^{-1}$, respectively. In addition, the (S)-NBHP yield was as high as $95.92 \%$ when whole cells of $E$. coli overexpressing ReCR variant Y54F catalyzed the asymmetric reduction of $1.5 \mathrm{M} \mathrm{NBPO}$ for $12 \mathrm{~h}$ in the aqueous / $(R / S)$-2-octanol biphasic system, demonstrating the great potential of ReCR variant Y54F for practical applications.
\end{abstract}

Keywords: (S)-N-Boc-3-hydroxypiperidine; carbonyl reductase; asymmetric reduction; rational design; Rhodococcus erythropolis

\section{Introduction}

Many natural products and active pharmaceutical ingredients share a common piperidine core, and the introduction of a chiral hydroxyl group on the C3-position of the piperidine ring may alter the bioactivity of the molecule [1-3]. (S)-N-Boc-3-hydroxypiperidine ((S)-NBHP) is a key chiral intermediate in the synthesis of ibrutinib as the inhibitor of Bruton's tyrosine kinase [4]. In the chemical synthesis of (S)-NBHP, employed strategies include the synthesis of racemic 3-hydroxypiperidine followed by chiral resolution and the enantiospecific synthesis of (S)-NBHP from chiral precursors. The former only achieves a maximum yield of 50\%, making the process economically unviable, while the latter appears to be limited because of the lengthy procedure, rather poor yields of the products, and the use of potentially hazardous reagents $[1,5,6]$. Alternatively, the carbonyl-reductase-catalyzed asymmetric reduction of $\mathrm{N}$-Boc-3-piperidone (NBPO) has gained increasing focus due to its mild reaction conditions, high yield, and remarkable enantioselectivity [4,7-9]. 
Coenzymes are required in carbonyl reductase-catalyzed reactions, and well-established approaches for coenzyme regeneration include the use of a second enzyme and a second substrate (i.e., glucose dehydrogenase and glucose), and the use of the second substrate catalyzed by the same enzyme (i.e., 2-propanol) [10]. Recently, an NADPH-dependent carbonyl reductase from Saccharomyces cerevisiae (YDR541C) was employed for the efficient synthesis of (S)-NBHP from NBPO by adopting a biphasic system to alleviate product inhibition and using glucose/glucose dehydrogenase to achieve coenzyme regeneration [8]. The glucose/glucose dehydrogenase system yields to the continuous production of gluconic acid; thus, $\mathrm{pH}$ adjustment is needed during the reaction, eventually making the process more complex and forming a large quantity of solid waste salt. Alternatively, the 2-propanol oxidation catalyzed by the same carbonyl reductase was widely used for coenzyme regeneration in order to simplify the operating process and increase the solubility of the substrates [11]. An efficient process catalyzed by the commercially-available ketoreductase KR-110 has been demonstrated to reduce $0.5 \mathrm{M}$ NBPO to render the (S)-NBHP yield of $97.6 \%$ after a $24-\mathrm{h}$ reaction [4]. The enzyme KR-110 was heat-sensitive and the substrate inhibition was obviously observed at a substrate concentration of $0.5 \mathrm{M}$. In addition, the 2-propanol concentration is usually required in excess to increase the product yield. Thus, high concentrations of the co-substrate together with the substrate further aggravate the inhibition of the enzyme activity in the 2-propanol-coupled strategy [4,11].

To overcome the inhibition from the high load of substrate/co-substrate, protein engineering is one of the promising approaches expanding the upper limit of the substrate/co-substrate concentration on a larger preparative scale $[12,13]$. Variants of the phenylacetaldehyde reductase from Rhodococcus sp. ST-10 (PAR) have been constructed through directed evolution, fully converting $200 \mathrm{~g} / \mathrm{L}$ ethyl 4-chloro-3-oxobutanoate into ethyl (S)-4-chloro-3-hydroxybutyrate in the presence of $15 \%(v / v)$ 2-propanol [14,15]. Furthermore, attempts with biphasic catalysis in the presence of water-immiscible organic solvents have demonstrated an intriguing potential for overcoming the inhibition from substrate/co-substrate, increasing the solubility of substrates, easy product removal, decreasing the spontaneous hydrolysis of substrate/product, and avoiding unfavorable equilibria [16-19]. In an aqueous/octanol biphasic system, the biosynthesis process of ethyl (R)-4-chloro-3-hydroxybutyrate using a stereoselective carbonyl reductase from Burkholderia gladioli was established, in which 1.2 M ethyl 4-chloro-3-oxobutanoate was completely converted to afford ethyl $(R)$-4-chloro-3-hydroxybutyrate through the substrate fed-batch strategy [20]. In addition, the integration of protein engineering and medium engineering can further improve the effectiveness of asymmetric reduction at a high substrate load [20-22].

Although several processes for the efficient biosynthesis of (S)-NBHP have been developed, the pivot carbonyl reductases as biocatalysts still lack an in-depth characterization. Our previous genome mining enabled the discovery of chiral ketoreductases from Rhodococcus erythropolis WZ010 and the exploration of its application in the synthesis of chiral alcohols [23,24]. Here, a strictly (S)-enantioselective carbonyl reductase from R. erythropolis WZ010 (ReCR) and its variant Y54F were characterized for the efficient bioreduction of NBPO to (S)-NBHP, providing a basis for process development with an efficient coenzyme regeneration employing $(R / S)$-2-octanol or 2-propanol as the co-substrate (Scheme 1). 


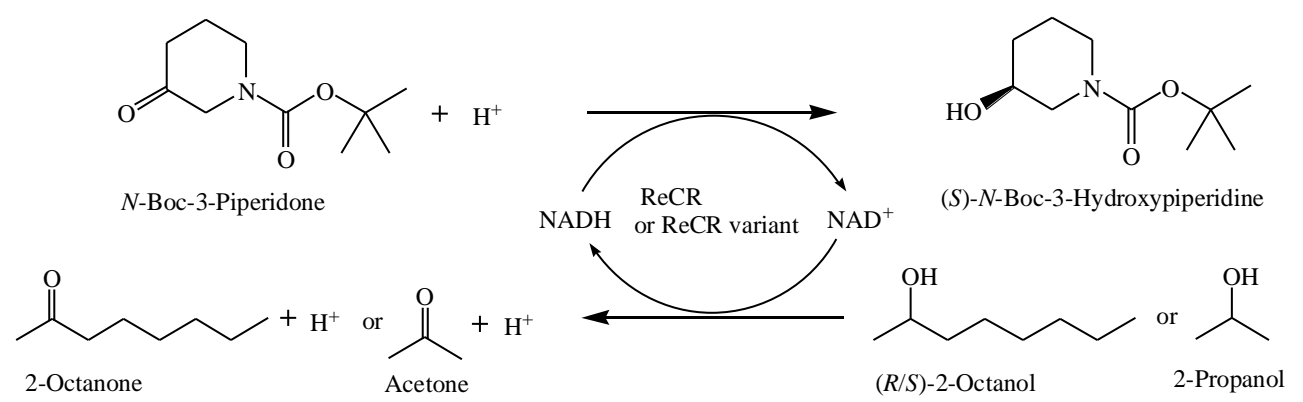

Scheme 1. Asymmetric bioreduction of $N$-Boc-3-piperidone (NBPO) using ( $R / S)$-2-octanol or 2-propanol as co-substrate for NADH regeneration.

\section{Results and Discussion}

\subsection{Characterization of Recombinant $\operatorname{ReCR}$}

The 1044-bp-long gene encoding ReCR was PCR-amplified from the genomic DNA of R. erythropolis WZ010 and over-expressed in E. coli BL21(DE3) in the form of the recombinant plasmid pEASY-E2-recr. The recombinant ReCR with C-terminal His-tag was subsequently purified by Ni-NTA chromatography. The gene recr encoded 348 amino acids with a deduced mass of $36.17 \mathrm{kDa}$, and the purified recombinant ReCR was verified with a single band of around $44 \mathrm{kDa}$ by SDS-PAGE (Figure 1). The encoded amino acid sequence of ReCR displayed a 98\% identity to that of PAR or alcohol dehydrogenase from R. erythropolis DSM 43297 (ReADH) [25-28], with five amino acids Arg67, Ser94, Lys110, Ser233, and Arg336 in ReCR different from Lys67, Asn94, Gln110, Lys233, and Gly336 in PAR or ReADH (Figure 2). The structure-related sequence alignment revealed that the enzyme belonged to the superfamily of zinc-containing alcohol dehydrogenases and had all conserved residues for the binding of catalytic and structural zinc ions [29]. It should be noted that the activity of the enzyme was severely inhibited by the exogenous zinc ion (Table S1), similar to what was observed with other zinc-containing alcohol dehydrogenases $[24,30]$.

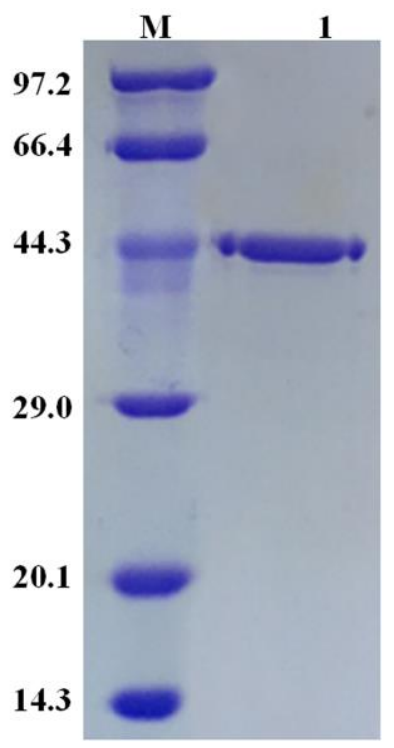

Figure 1. SDS-PAGE (12.5\%) analysis of the purified recombinant ReCR. Lane 1, $2 \mu \mathrm{g}$ purified ReCR with C-terminal His-tag; lane M, molecular weight marker. Coomassie Brilliant Blue R-250 was used to visualize the protein bands in the SDS-PAGE gel. 

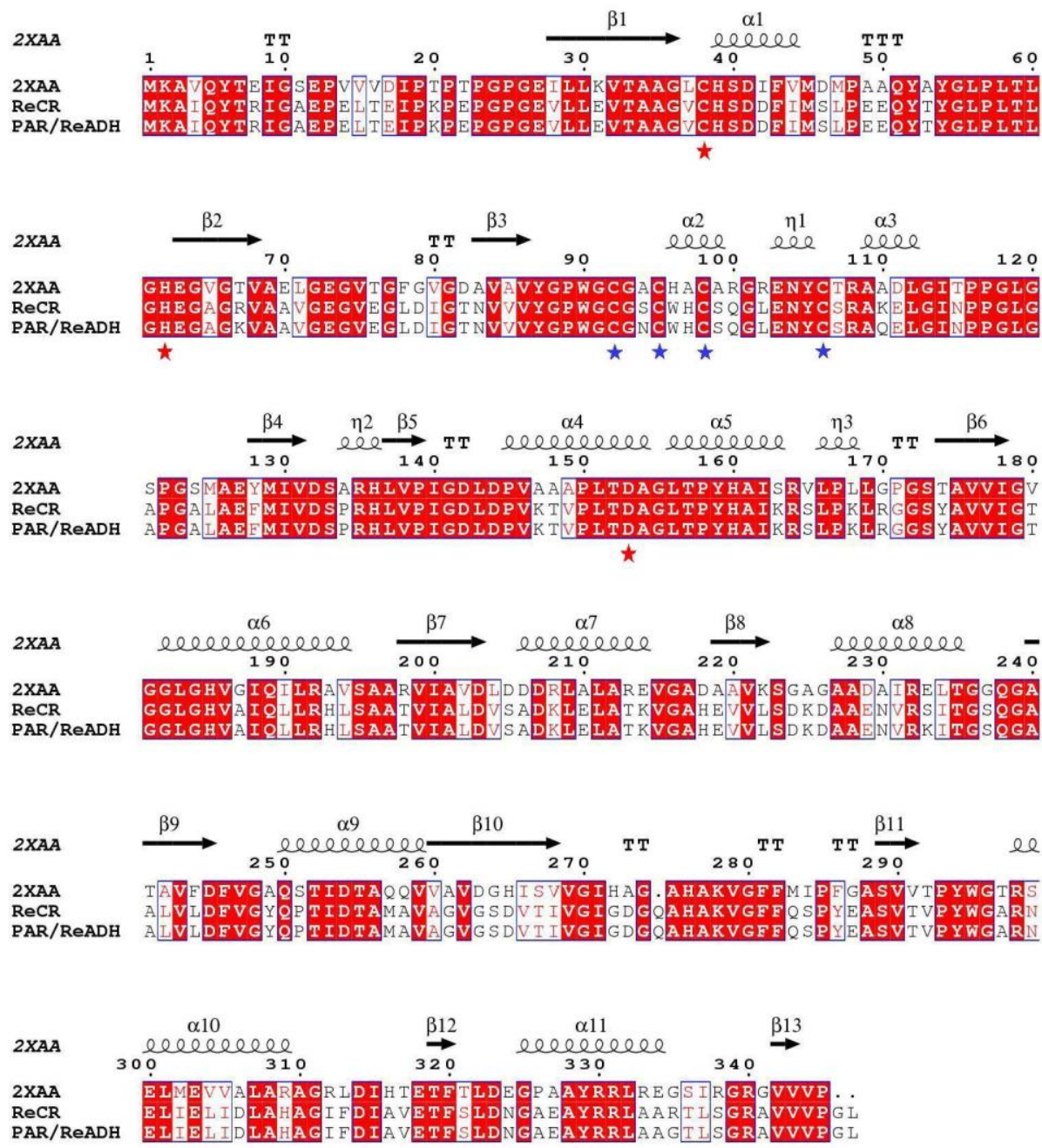

Figure 2. Structure-related sequence alignment between ReCR and its homologous proteins. 2XAA, PDB code of alcohol dehydrogenase from Rhodococcus ruber DSM 44541; PAR, alcohol dehydrogenase from Rhodococcus sp. ST-10 (GenBank accession No.: AB020760.3); ReADH, alcohol dehydrogenase from $R$. erythropolis DSM 43297 (GenBank accession No.: AY161280.1). The amino acid sequences of both PAR and ReADH are identical. Shown above the alignments are elements of the secondary structure of 2XAA. The numbering shown is from 2XAA. Red stars, putative catalytic residues; blue stars, residues for the coordination of structural zinc. Strictly conserved residues are highlighted with red boxes.

The recombinant $\mathrm{ReCR}$ was strictly $\mathrm{NAD}^{+}$-dependent, since the enzyme activity was not detectable when $\mathrm{NADP}(\mathrm{H})$ was used as a coenzyme. The effect of $\mathrm{pH}$ on the activity was investigated within the $\mathrm{pH}$ range of 5.5-10.5. The maximum activities for NBPO reduction and $(R / S)$-2-octanol oxidation were observed at $\mathrm{pH} 6.0$ and 10.0, respectively (Figure 3A), indicating that ReCR-catalyzed oxidation/reduction was $\mathrm{pH}$-dependent [24]. The optimal temperature was $60^{\circ} \mathrm{C}$ for NBPO reduction and $50{ }^{\circ} \mathrm{C}$ for $(R / S)$-2-octanol oxidation (Figure 3B). The enzyme activity in NBPO reduction was stable at $35^{\circ} \mathrm{C}$, whereas the remaining activity decreased to $50 \%$ of the initial activity after heat treatment at $60^{\circ} \mathrm{C}$ for $1.5 \mathrm{~h}$ or $55^{\circ} \mathrm{C}$ for $6.5 \mathrm{~h}$ (Figure $4 \mathrm{~A}$ ), demonstrating that its thermostability was superior to the heat-sensitive enzyme KR-110 [4]. Among the tested organic solvents, $20 \%(v / v)$ 2-propanol drastically decreased the activity of ReCR, similar to the performance of PAR in the presence of $>10 \%(v / v)$ 2-propanol [18]. In contrast to $20 \%(v / v)$ 2-propanol, the enzyme displayed higher stability after $3.5 \mathrm{~h}$ incubation with $40 \%(v / v)(R / S)$-2-octanol (Figure $4 \mathrm{~B})$. 

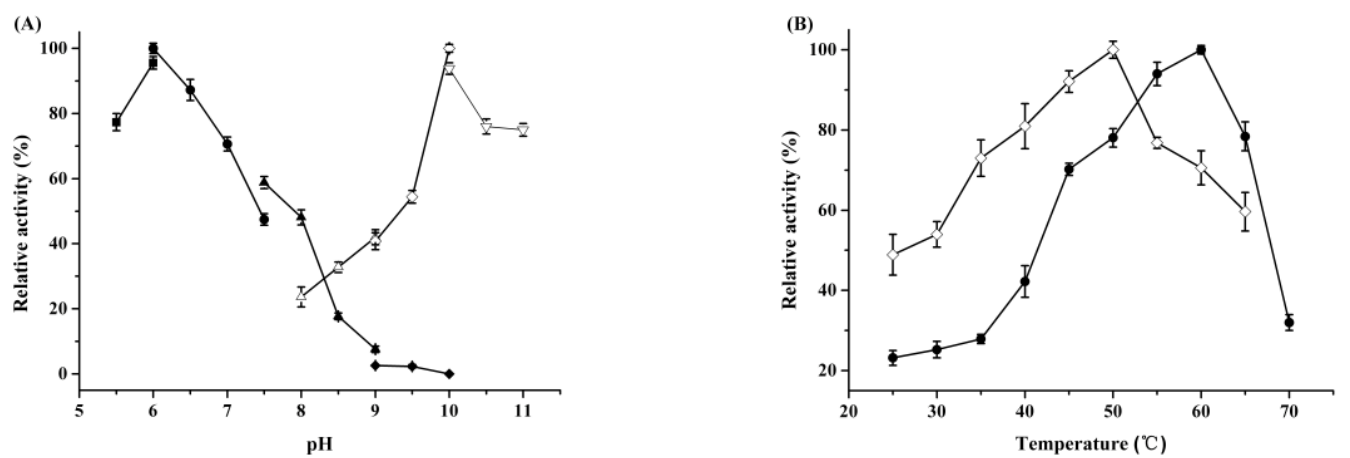

Figure 3. Effect of $\mathrm{pH}(\mathbf{A})$ and temperature (B) on the activity of recombinant ReCR. The relative activities of $100 \%$ represent $85.8 \mathrm{U} / \mathrm{mg}$ for NBPO reduction (solid symbols) and $88.3 \mathrm{U} / \mathrm{mg}$ for $(R / S)$-2-octanol oxidation (open symbols). The buffers 2 -( $N$-morpholino)ethanesulfonic acid (MES, $\mathbf{\square})$, piperazine-1,4-bisethanesulfonic acid(PIPES, $\bullet$ ), Tris- $\mathrm{HCl}(\mathbf{\Delta})$, and 3-(cyclohexylamino)-2hydroxy-1-propanesulfonic acid (CAPSO, $\diamond)$ were used for the reduction reaction, while the buffers Tris-HCl $(\triangle)$, CAPSO $(\diamond)$, and 3-(cyclohexylamino)-1-propanesulfonic acid (CAPS, $\nabla)$ were used for the oxidation reaction.
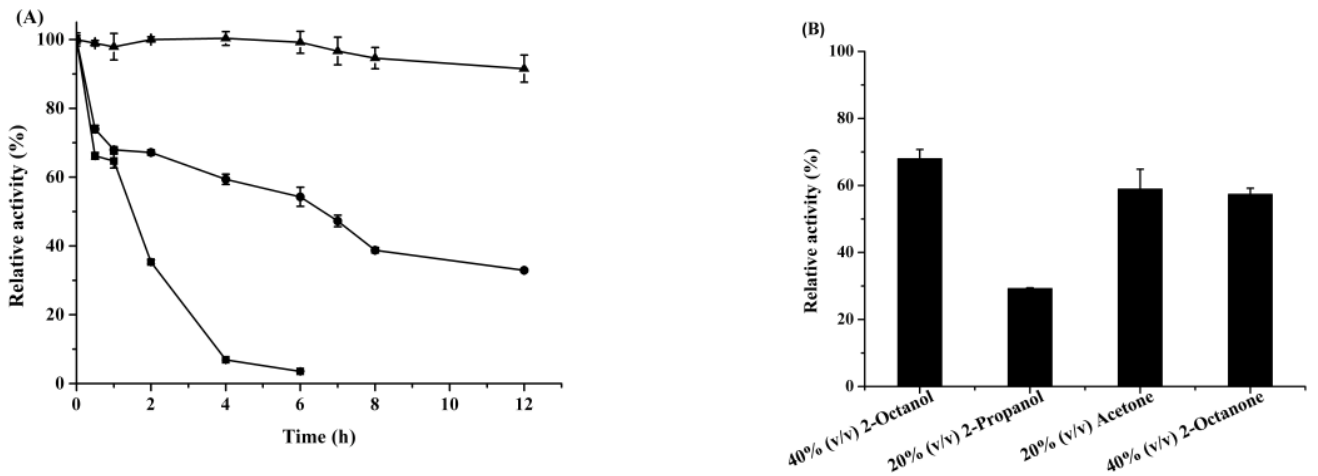

Figure 4. The stability of ReCR against heat (A) and organic solvents (B). Symbols: ( $\mathbf{\square})$ for $60{ }^{\circ} \mathrm{C}$, (•) for $55{ }^{\circ} \mathrm{C},(\boldsymbol{\Delta})$ for $35^{\circ} \mathrm{C}$. The relative activity of $100 \%$ represents $85.8 \mathrm{U} / \mathrm{mg}$ for NBPO reduction. The enzyme was incubated with organic solvent $(40 \%(v / v)(R / S)$-2-octanol, 40\% (v/v) 2-octanone, $20 \%(v / v)$ 2-propanol, or $20 \%(v / v)$ acetone) at $35{ }^{\circ} \mathrm{C}$ for $3.5 \mathrm{~h}$ prior to the stability test against organic solvent.

The substrate specificity of ReCR was tested using a set of alcohols and ketones (Table 1). Among the tested substrates, the enzyme exhibited the highest activities with 2,3-butanedione in the ketone reduction and $(R / S)$-2-octanol in the alcohol oxidation. The purified ReCR presented an activity of 85.8 U/mg towards NBPO reduction at $\mathrm{pH} 6.0$ and $60^{\circ} \mathrm{C}$. Distinct from PAR and its variants [14], the activity of ReCR toward N-Boc-3-pyrrolidone reduction was relatively low. Particularly, the activity towards the oxidation of either $(S)$ - or $(R)$-NBHP was not detectable at various temperatures $\left(25-75^{\circ} \mathrm{C}\right)$ and pHs (6.0-10.0), suggesting that the ReCR-catalyzed NBPO reduction was irreversible. A similar case was the secondary alcohol dehydrogenase SdcA from $R$. erythropolis DSM 44534 catalyzing the irreversible (S)-2-octanol oxidation [31]. The $K_{\mathrm{m}}$ and $k_{\text {cat }} / K_{\mathrm{m}}$ values for NBPO were $1.74 \mathrm{mM}$ and $35.98 \mathrm{~s}^{-1} \mathrm{mM}^{-1}$, respectively (Table 2). The $k_{\text {cat }} / K_{\mathrm{m}}$ value for $(R / S)$-2-octanol and 2-propanol was $13.04 \mathrm{~s}^{-1} \mathrm{mM}^{-1}$ and $9.74 \mathrm{~s}^{-1} \mathrm{mM}^{-1}$, respectively, implying that the use of $(R / S)$-2-octanol or 2-propanol as a co-substrate could be feasible to regenerate NADH in the NBPO reduction. 
Table 1. Substrate spectrum of recombinant ReCR against ketones and alcohols ${ }^{\text {a }}$.

\begin{tabular}{|c|c|c|c|}
\hline Substrate & Relative Activity (\%) & Substrate & Relative Activity (\%) \\
\hline N-Boc-3-Piperidone & $100.0^{b} \pm 2.6$ & $(R / S)$-2-Octanol & $100.0^{c} \pm 1.6$ \\
\hline 2,3-Butanedione & $189.0 \pm 3.4$ & $(R / S)$-2-Pentanol & $61.8 \pm 2.3$ \\
\hline 2-Octanone & $169.2 \pm 2.9$ & 2-Propanol & $47.4 \pm 0.5$ \\
\hline$p$-Bromoacetophenone & $143.9 \pm 4.3$ & $(R / S)$-2-Butanol & $43.8 \pm 1.1$ \\
\hline Acetoin & $47.2 \pm 0.7$ & DL-1-Phenylethanol & $31.5 \pm 2.1$ \\
\hline$\beta$-Ionone & $34.8 \pm 1.2$ & Cyclohexanol & $8.0 \pm 1.0$ \\
\hline 4-Hydroxy-2-butanone & $31.8 \pm 1.1$ & 2-Buten-1-ol & $6.8 \pm 0.2$ \\
\hline 3-Octen-2-one & $25.7 \pm 0.7$ & (S)-N-Boc-3-Pyrrolidinol & $2.7 \pm 0.4$ \\
\hline Acetophenone & $25.3 \pm 1.0$ & (S)-N-Boc-3-Hydroxypiperidine & 0 \\
\hline Hydroxyacetone & $23.6 \pm 0.6$ & (R)-N-Boc-3-Hydroxypiperidine & 0 \\
\hline N-Boc-3-Pyrrolidone & $9.2 \pm 0.5$ & & \\
\hline Acetone & $4.8 \pm 0.3$ & & \\
\hline 2-Bromoacetophenone & $1.8 \pm 0.1$ & & \\
\hline
\end{tabular}

${ }^{a}$ Data present mean values \pm SD from two independent experiments. ${ }^{b}$ Relative activity of $100 \%$ represents 85.8 $\mathrm{U} / \mathrm{mg}$ for NBPO reduction at $\mathrm{pH} 6.0$ and $60^{\circ} \mathrm{C} ;{ }^{\mathrm{c}}$ Relative activity of $100 \%$ represents $88.3 \mathrm{U} / \mathrm{mg}$ for $(R / S)$-2-octanol oxidation at $\mathrm{pH} 10.0$ and $50^{\circ} \mathrm{C}$.

Table 2. Kinetic parameters of recombinant $\operatorname{ReCR}^{\mathrm{a}}$.

\begin{tabular}{|c|c|c|c|c|c|}
\hline Substrate & $\begin{array}{l}\text { Coenzyme } \\
(\mathrm{mM})\end{array}$ & $\begin{array}{c}V_{\max } \\
\left(\mathrm{U} \mathrm{mg}^{-1}\right)\end{array}$ & $\begin{array}{c}K_{\mathrm{m}} \\
(\mathrm{mM})\end{array}$ & $\begin{array}{l}k_{\mathrm{cat}} \\
\left(\mathrm{s}^{-1}\right)\end{array}$ & $\begin{array}{c}k_{\text {cat }} / K_{\mathrm{m}} \\
\left(\mathrm{s}^{-1} \mathrm{mM}^{-1}\right)\end{array}$ \\
\hline NBPO & NADH (0.4) & $103.57 \pm 2.46$ & $1.74 \pm 0.08$ & $62.61 \pm 1.49$ & $35.98 \pm 0.86$ \\
\hline (S)-NBHP & $\mathrm{NAD}^{+}(0.4)$ & $\mathrm{ND}^{\mathrm{b}}$ & $\mathrm{ND}^{\mathrm{b}}$ & $\mathrm{ND}^{\mathrm{b}}$ & $\mathrm{ND}^{\mathrm{b}}$ \\
\hline Acetone & NADH (0.4) & $66.30 \pm 3.27$ & $46.06 \pm 2.62$ & $40.08 \pm 1.98$ & $0.87 \pm 0.04$ \\
\hline 2-Propanol & $\mathrm{NAD}^{+}(0.4)$ & $23.54 \pm 0.27$ & $1.46 \pm 0.06$ & $14.22 \pm 0.16$ & $9.74 \pm 0.11$ \\
\hline 2-Octanone & NADH (0.4) & $235.54 \pm 5.95$ & $3.29 \pm 0.05$ & $142.38 \pm 3.11$ & $43.28 \pm 0.95$ \\
\hline$(R / S)$-2-Octanol & $\mathrm{NAD}^{+}(0.4)$ & $106.57 \pm 2.74$ & $4.94 \pm 0.45$ & $64.42 \pm 1.66$ & $13.04 \pm 0.34$ \\
\hline
\end{tabular}

${ }^{\mathrm{a}}$ Data present mean values \pm SD from three independent experiments. ${ }^{\mathrm{b}} \mathrm{ND}$, not detectable.

\subsection{Rational Design and Characterization of ReCR Variant Y54F}

For the in-depth characterization, attempts of rational design of ReCR were conducted to improve its activity. The ReCR homology model was built based on the X-ray crystal structure of ADH-A from Rhodococcus ruber (PDB: 2XAA). Sequence identity of ReCR towards ADH-A was 60\%. The QMEAN and Z-score values were used for the quality evaluation of the models. The QMEAN and Z-score values of the ReCR homology model were 0.822 and 0.533 , respectively, which indicated satisfactory quality. In Ramachandran Plot analysis, $91.5 \%$ of residues were located in a favorable region, and only $0.4 \%$ were found in the sterically disallowed region. This ReCR homology model was selected for subsequent docking studies.

Furthermore, substrate docking was employed to predict potentially beneficial amino acid positions on ReCR. Figure 5A shows that NBPO was ideally accommodated in the ligand binding pocket of ReCR composed by zinc ion, NADH, and Tyr54 (in the vicinity of the entrance to the active site). Similar to the binding mode of ADH-A with the substrate [29], the carbonyl oxygen atom of NBPO in ReCR was bound to the $\mathrm{Zn}^{2+}$ ion with a distance of $4.1 \AA$, and the carbonyl carbon atom was in close proximity to the C4-atom of NADH. Thus, the hydride was transferred onto the re-face of the carbonyl group, consistent with the strict (S)-enantioselectivity of ReCR. On the other hand, the bulky Boc group of NBPO was close to the hydroxyl group of Tyr54 (distance of $4.3 \AA$ between the hydroxyl oxygen of Tyr and the tertiary carbon of the Boc group), which might cause a steric hindrance during the substrate binding (Figure 5). Therefore, Tyr54 was selected to be mutated to Phe. 


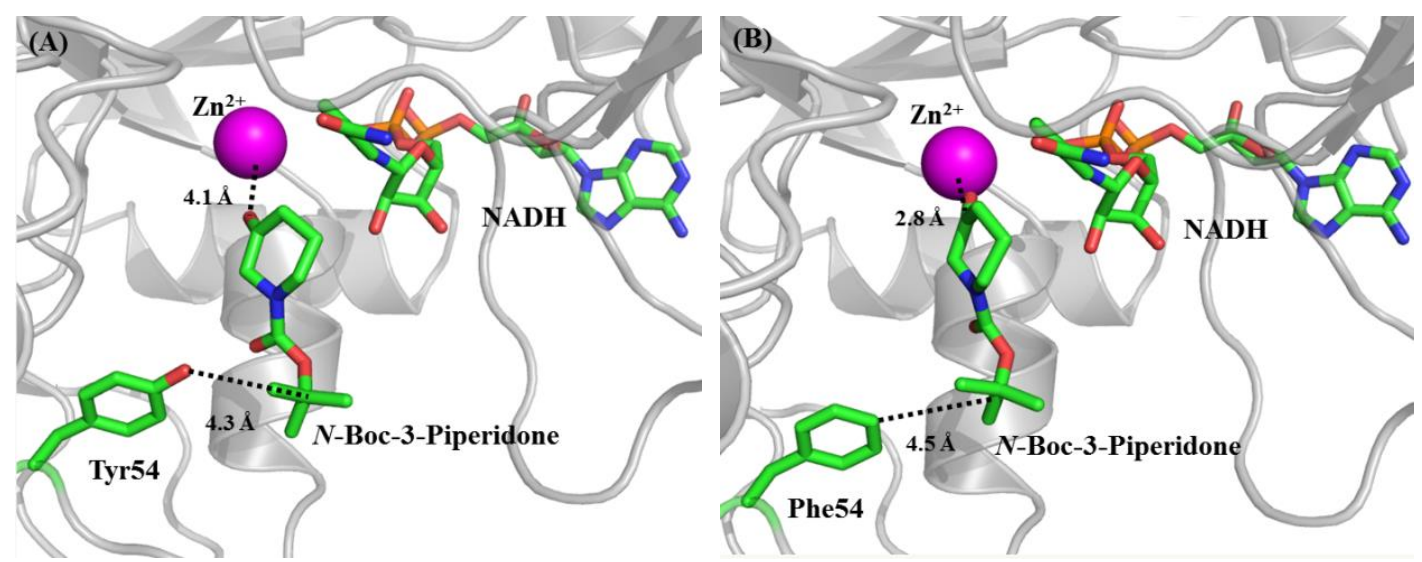

Figure 5. Protein-ligand structures of ReCR with NBPO (A) and ReCR Y54F with NBPO (B). ReCR and ReCR Y54F are represented in cartoon format. Tyr54, Phe54, NADH, and NBPO are highlighted in sticks. The zinc ion is shown as a magenta sphere.

As anticipated, the substitution of Tyr54 to Phe significantly improved the catalytic performance of ReCR, implying that the amino acid residue at position 54 could be critical for the enzyme activity. In the ketone reduction, the $k_{\text {cat }} / K_{\mathrm{m}}$ values of ReCR Y54F for NBPO $\left(49.17 \mathrm{~s}^{-1} \mathrm{mM}^{-1}\right)$, acetone $\left(1.47 \mathrm{~s}^{-1} \mathrm{mM}^{-1}\right)$, and 2-octanone $\left(53.21 \mathrm{~s}^{-1} \mathrm{mM}^{-1}\right)$ were 1.37, 1.69, and 1.23 times higher than those of $\operatorname{ReCR}\left(35.98 \mathrm{~s}^{-1} \mathrm{mM}^{-1}, 0.87 \mathrm{~s}^{-1} \mathrm{mM}^{-1}\right.$, and $43.28 \mathrm{~s}^{-1} \mathrm{mM}^{-1}$ ), respectively (Tables 2 and 3). In the alcohol oxidation, the $k_{\text {cat }} / K_{\mathrm{m}}$ values of ReCR Y54F for $(R / S)$-2-octanol $\left(56.56 \mathrm{~s}^{-1} \mathrm{mM}^{-1}\right)$ and 2-propanol (20.69 s s $\left.\mathrm{mM}^{-1}\right)$ were 4.34 and 2.12 times higher than those of $\operatorname{ReCR}\left(13.04 \mathrm{~s}^{-1} \mathrm{mM}^{-1}\right.$ and $9.74 \mathrm{~s}^{-1} \mathrm{mM}^{-1}$ ), respectively (Tables 2 and 3). Although the $K_{\mathrm{m}}$ value of ReCR Y54F for NBPO $(1.74 \mathrm{mM})$ was similar to that of ReCR, the $K_{\mathrm{m}}$ values of ReCR Y $54 \mathrm{~F}$ for other tested substrates were lowered to a certain extent.

Table 3. Kinetic parameters of ReCR variant $\mathrm{Y} 54 \mathrm{~F}^{\mathrm{a}}$.

\begin{tabular}{cccccc}
\hline Substrate & $\begin{array}{c}\text { Coenzyme } \\
(\mathbf{m M})\end{array}$ & $\begin{array}{c}\boldsymbol{V}_{\mathbf{m a x}} \\
\left(\mathbf{U ~ m}^{-\mathbf{1}}\right)\end{array}$ & $\begin{array}{c}\boldsymbol{K}_{\mathbf{m}} \\
(\mathbf{m M} \mathbf{M})\end{array}$ & $\begin{array}{c}\boldsymbol{k}_{\text {cat }} \\
\left(\mathbf{s}^{-\mathbf{1}}\right)\end{array}$ & $\begin{array}{c}\boldsymbol{k}_{\text {cat }} / \boldsymbol{K}_{\mathbf{m}} \\
\left(\mathbf{s}^{-\mathbf{1}} \mathbf{m M}^{-\mathbf{1}} \mathbf{)}\right.\end{array}$ \\
\hline $\mathrm{NBPO}$ & $\mathrm{NADH}(0.4)$ & $140.72 \pm 6.52$ & $1.73 \pm 0.05$ & $85.07 \pm 3.94$ & $49.17 \pm 2.28$ \\
$(S)-\mathrm{NBHP}$ & $\mathrm{NAD}^{+}(0.4)$ & $\mathrm{ND}^{\mathrm{b}}$ & $\mathrm{ND}^{\mathrm{b}}$ & $\mathrm{ND}^{\mathrm{b}}$ & $\mathrm{ND}^{\mathrm{b}}$ \\
Acetone & $\mathrm{NADH}^{\mathrm{b}}(0.4)$ & $90.46 \pm 1.69$ & $37.32 \pm 0.56$ & $54.68 \pm 1.02$ & $1.47 \pm 0.03$ \\
2-Propanol & $\mathrm{NAD}^{+}(0.4)$ & $35.29 \pm 0.88$ & $1.03 \pm 0.05$ & $21.32 \pm 0.53$ & $20.69 \pm 0.51$ \\
2-Octanone & $\mathrm{NADH}^{(0.4)}$ & $273.75 \pm 7.58$ & $3.11 \pm 0.12$ & $165.48 \pm 4.58$ & $53.21 \pm 1.47$ \\
$(R / S)-2-O c t a n o l$ & $\mathrm{NAD}^{+}(0.4)$ & $128.19 \pm 3.12$ & $1.37 \pm 0.08$ & $77.49 \pm 1.88$ & $56.56 \pm 1.37$ \\
\hline
\end{tabular}

${ }^{a}$ Data present mean values \pm SD from three independent experiments. ${ }^{b} \mathrm{ND}$, not detectable.

Consistently with kinetic parameters, the productivity of asymmetric bioreduction of NBPO was significantly enhanced when whole cells overexpressing ReCR Y54F instead of ReCR were used as biocatalyst (Table 4). In contrast to the free enzyme, the use of a whole-cell biocatalyst was chosen because of higher enzyme stability and simpler procedure of biocatalyst preparation $[4,11,32]$. Both 2-propanol and $(R / S)$-2-octanol were investigated as co-substrates for the NADH regeneration. In the presence of $10 \%(v / v)$ 2-propanol, the bioreduction of $0.5 \mathrm{M} \mathrm{NBPO}$ catalyzed by whole cells overexpressing ReCR Y54F gave a (S)-NBHP yield of $98.08 \%$ after $12 \mathrm{~h}$, which was 1.34 times higher than that of $\operatorname{ReCR}(72.15 \%)$. The whole-cell biphasic system has been demonstrated to be effective at a higher substrate load, in which $(R / S)$-2-octanol instead of 2-propanol was used not only as co-substrate for coenzyme regeneration but also as the organic phase for the substrate reservoir and product sink $[33,34]$. In the aqueous/(R/S)-2-octanol biphasic system, the (S)-NBHP yield was increased from $77.78 \%$ to $95.92 \%$ when ReCR Y54F replaced ReCR in the whole-cell biocatalyst. The corresponding total turnover number value of 1199 , the calculated space-time yield of $579.15 \mathrm{~g} \mathrm{~L}^{-1}$ day $^{-1}$, and the 
remarkable stereoselectivity (e.e.p > 99.9\%) together with the substrate concentration (up to $1.5 \mathrm{M}$ ) demonstrated a great potential of ReCR variant Y54F in the practical synthesis of (S)-NBHP.

Table 4. Asymmetric reduction of N-Boc-3-piperidone catalyzed by whole cells overexpressing ReCR or $\operatorname{ReCR}$ Y54F ${ }^{a}$.

\begin{tabular}{ccccc}
\hline Enzyme $^{\mathbf{b}}$ & Substrate (M) & Co-substrate (v/v) & Yield (\%) & e.e.p (\%) \\
\hline ReCR & NBPO, 0.5 & 2-Propanol, 10\% & $72.15 \pm 3.51$ & $>99.9(S)$ \\
ReCR Y54F & NBPO, 0.5 & 2-Propanol, 10\% & $98.08 \pm 1.65$ & $>99.9(S)$ \\
ReCR & NBPO, 1.5 & $(R / S)-2-O c t a n o l, 60 \%$ & $77.78 \pm 2.23$ & $>99.9(S)$ \\
$\operatorname{ReCR~Y54F~}$ & NBPO, 1.5 & $(R / S)-2-O c t a n o l, 60 \%$ & $95.89 \pm 2.37$ & $>99.9(S)$
\end{tabular}

a Data present mean values \pm SD from two independent experiments. ${ }^{b}$ Whole cells overexpressing ReCR or ReCR variant Y54F. ${ }^{c}$ The e.e.p value ( $\left.>99.9 \%\right)$ means that no $(R)-\mathrm{NBHP}$ peak was detected during GC analyses.

\section{Materials and Methods}

\subsection{Strain and Growth Condition}

The strain R. erythropolis WZ010 was deposited in the China Center for Type Culture Collection (CCTCC M 2011336) and used as the donor of the gene recr encoding the carbonyl reductase ReCR [35]. The host strains E. coli Trans1-T1 and E. coli BL21(DE3) were used for the purposes of cloning and over-expression, respectively. Both R. erythropolis WZ010 and E. coli strains were cultured at $30{ }^{\circ} \mathrm{C}$ and $200 \mathrm{rpm}$ for $24 \mathrm{~h}$ in Luria-Bertani (LB) medium with a $\mathrm{NaCl}$ concentration of $5 \mathrm{~g} / \mathrm{L}$, unless stated otherwise.

\subsection{Construction, Expression, and Purification of Recombinant Enzyme ReCR}

The gene recr was PCR-amplified from the genomic DNA of $R$. erythropolis WZ010 using forward and reverse primers: recrF1 (5'-ATGAAGGCAATCCAGTACAC-3') and recrR1 (5'-CTACAGACCAG GGACCACA- $3^{\prime}$ ). The PCR conditions were listed as follows: denaturalization, $94{ }^{\circ} \mathrm{C}$ for $4 \mathrm{~min}$; 30 cycles of $94{ }^{\circ} \mathrm{C}$ for $30 \mathrm{~s}, 53.5^{\circ} \mathrm{C}$ for $30 \mathrm{~s}$, and $72{ }^{\circ} \mathrm{C}$ for $1 \mathrm{~min}$; and the final extension, $72{ }^{\circ} \mathrm{C}$ for $10 \mathrm{~min}$. According to TA cloning strategy from the instructions of the pEASY-E2 expression kit (TransGen Biotech Co., Ltd., Beijing, China), the PCR product was subcloned into the expression vector pEASY-E2 to form the recombinant vector pEASY-E2-recr with the C-terminal His-tag. The recombinant plasmid was then transformed into Trans1-T1 competent cells and the recombinant cells were cultured at $37^{\circ} \mathrm{C}$ and $200 \mathrm{rpm}$ in LB medium with $100 \mu \mathrm{g} / \mathrm{mL}$ ampicillin (Amp). The recombinant cell named as E. coli Trans1-T1/pEASY-E2-recr was selected by colony PCRs and the recombinant plasmid pEASY-E2-recr was further extracted and verified by DNA sequencing (Sunny Biotechnology, Shanghai, China).

The recombinant plasmid pEASY-E2-recr was extracted and then transformed into E. coli BL21(DE3) competent cells. The positive recombinant cell named as E. coli BL21(DE3)/pEASY-E2-recr was cultured at $37{ }^{\circ} \mathrm{C}$ and $200 \mathrm{rpm}$ in LB medium with $100 \mu \mathrm{g} / \mathrm{mL}$ Amp. When the $\mathrm{OD}_{600}$ reached 0.6, isopropyl $\beta$-D-1-thiogalactopyranoside (IPTG) was added to the culture at a final concentration of $0.3 \mathrm{mM}$, and the temperature was maintained at $20^{\circ} \mathrm{C}$. After $20 \mathrm{~h}$ incubation, the E. coli cells were harvested by centrifugation and the expression level was analyzed by sodium dodecyl sulfate-polyacrylamide gel electrophoresis (SDS-PAGE). Following the same procedure in the study of 2,3-butanediol dehydrogenase from R. erythropolis WZ010 [24], the recombinant ReCR with C-terminal His-tag was purified to homogeneity by nickel affinity chromatography, desalted with $50 \mathrm{mM}$ Tris- $\mathrm{HCl}$ ( $\mathrm{pH}$ 8.0) by ultrafiltration, and stored at $-20^{\circ} \mathrm{C}$ for further characterization. The subunit molecular mass and purity of ReCR were verified by SDS-PAGE as described previously [36].

\subsection{Enzyme Activity Assays and Characterization of Recombinant ReCR}

The ReCR enzyme activity was measured by the reduction of $\mathrm{NAD}^{+}$or oxidation of $\mathrm{NADH}$ at $340 \mathrm{~nm}\left(\varepsilon_{340}=6.3 \mathrm{mM}^{-1} \mathrm{~cm}^{-1}\right)$. Unless otherwise specified, the standard enzyme activity assay for 
the ketone reduction was performed at $60{ }^{\circ} \mathrm{C}$ in duplicate using the assay mixture $(2.5 \mathrm{~mL})$ containing $10 \mathrm{mM}$ NBPO, $0.4 \mathrm{mM}$ NADH, and $50 \mathrm{mM}$ PIPES buffer (pH 6.0). The standard assay mixture (2.5 mL) for the alcohol oxidation at $50{ }^{\circ} \mathrm{C}$ contained $50 \mathrm{mM}(R / S)$-2-octanol, $0.4 \mathrm{mM} \mathrm{NAD}{ }^{+}$, and $50 \mathrm{mM}$ CAPSO buffer ( $\mathrm{pH} 10.0$ ). Unless stated otherwise, the reduction and oxidation reactions were initiated by the addition of $5 \mu \mathrm{g}$ purified enzyme, respectively. One unit of activity was defined as the amount of enzyme that oxidized or reduced $1 \mu \mathrm{mol} \mathrm{NADH}$ or $\mathrm{NAD}^{+}$per minute under optimal $\mathrm{pH}$ and temperature. The protein concentrations of ReCR samples were determined using the Bradford reagent with bovine serum albumin as the standard protein.

The optimal temperature of ReCR activity was determined at a series of temperatures ranging from 25 to $70{ }^{\circ} \mathrm{C}$ using $50 \mathrm{mM}$ PIPES buffer ( $\mathrm{pH}$ 6.0) for NBPO reduction or $50 \mathrm{mM}$ CAPSO buffer (pH 10.0) for $(R / S)$-2-octanol oxidation. The optimal $\mathrm{pH}$ of $\mathrm{ReCR}$ activity was determined over a range of $\mathrm{pH}$ from 5.5 to 11.0 at $60^{\circ} \mathrm{C}$ for $\mathrm{NBPO}$ reduction or $50{ }^{\circ} \mathrm{C}$ for $(R / S)$-2-octanol oxidation. The buffers $(50 \mathrm{mM})$ used were 2-(N-morpholino)ethanesulfonic acid (MES, pH 5.5-6.0), piperazine-1,4-bisethanesulfonic acid (PIPES, pH 6.1-7.5), Tris-HCl (pH 7.5-9.0), 3-(cyclohexylamino)-2-hydroxy-1-propanesulfonic acid (CAPSO, pH 9.0-10.0), and 3-(cyclohexylamino)-1-propanesulfonic acid (CAPS, pH 10.0-11.0). All the $\mathrm{pH}$ values of the buffers used were determined at $25{ }^{\circ} \mathrm{C}$ using a Mettler Toledo FE20 FiveEasy pH Meter (Mettler-Toledo (Schweiz) GmbH, Greifensee, Switzerland).

The thermostability of the ReCR was investigated by determining its residual activities when the enzyme samples were incubated at $35^{\circ} \mathrm{C}, 55^{\circ} \mathrm{C}$, or $60^{\circ} \mathrm{C}$. To determine the stability in the presence of organic solvents, the enzyme was incubated with organic solvent at $35^{\circ} \mathrm{C}$ for $3.5 \mathrm{~h}$ and then the residual activities were assayed for NBPO reduction. The determination of kinetic constants for ReCR was carried out using different substrates. The substrates were NBPO (0-20 mM), acetone (0-1 M), 2-propanol (0-70 mM), 2-octanone (0-30 mM), and (R/S)-2-octanol (0-20 mM). Apparent values of $K_{\mathrm{m}}$ and $V_{\text {max }}$ were calculated using a non-linear regression curve fitting to the Michaelis-Menten equation with the software Origin 8.0 (OriginLab Corporation, Northampton, UK). Data of kinetic parameters present mean values \pm SD from three independent experiments.

\subsection{Asymmetric Reduction of NBPO Catalyzed by Whole Cells of E. coli BL21(DE3)/pEASY-E2-recr}

The asymmetric reduction of NBPO was carried out using $(R / S)$-2-octanol or 2-propanol as a co-substrate for the coenzyme regeneration. In the case of 2-propanol as the co-substrate, the reaction mixture $(5 \mathrm{~mL})$ contained $0.5 \mathrm{M} \mathrm{NBPO}, 10 \%(v / v)$ 2-propanol, $0.4 \mathrm{mM} \mathrm{NAD}^{+}$, and $0.4 \mathrm{~g}$ wet cells in $50 \mathrm{mM}$ Tris-HCl buffer ( $\mathrm{pH} 8.0)$. In the aqueous $/(R / S)$-2-octanol biphasic system, the reaction mixture $(5 \mathrm{~mL})$ contained 1.5 M NBPO, 60\% $(v / v)(R / S)$-2-octanol, $1.2 \mathrm{mM} \mathrm{NAD}^{+}$, and $1.2 \mathrm{~g}$ wet cells in $50 \mathrm{mM}$ Tris- $\mathrm{HCl}$ buffer ( $\mathrm{pH}$ 8.0). The reactions were carried out in a C76 Water Bath Shaker (New Brunswick, Edison, NJ, USA) at $35^{\circ} \mathrm{C}$ and $300 \mathrm{rpm}$ for $12 \mathrm{~h}$.

The reaction mixture was extracted with $5 \mathrm{~mL}$ of ethyl acetate under strong vibration. The organic phase in the samples was separated by centrifugation and dehydrated with anhydrous sodium sulfate; then, $1 \mu \mathrm{L}$ dehydrated sample was applied onto the injector $\left(250{ }^{\circ} \mathrm{C}\right)$ for $\mathrm{GC}$ analysis. The reactants were determined with an Agilent 6890N (Santa Clara, CA, USA) gas chromatograph equipped with a chiral GC column (BGB174, $30 \mathrm{~m} \times 250 \mu \mathrm{m} \times 0.25 \mu \mathrm{m}$ ). The temperature program for GC analysis was set as follows: $5{ }^{\circ} \mathrm{C} / \mathrm{min}$ from $100{ }^{\circ} \mathrm{C}$ to $125^{\circ} \mathrm{C}$, hold $3 \mathrm{~min} ;{ }^{\circ} \mathrm{C} / \mathrm{min}$ to $140{ }^{\circ} \mathrm{C}$, hold $8 \mathrm{~min}$; $1^{\circ} \mathrm{C} / \mathrm{min}$ to $150{ }^{\circ} \mathrm{C}$. The peak areas were quantitated using specific external standards. The standards NBPO, (S)-NBHP, and (R)-NBHP were purchased from Sigma-Aldrich Corporation (Shanghai, China). Retention times of the reactants were listed as follows: $26.997 \mathrm{~min}$ for NBPO, $28.452 \mathrm{~min}$ for $(S)$-NBHP, and $28.739 \mathrm{~min}$ for $(R)-\mathrm{NBHP}$ (Figure S1). Specifically, the (S)-NBHP peak was further determined by GC-MS analysis (Figure S2).

\subsection{Construction, Characterization, and Docking Analysis of ReCR Variant Y54F}

Site-specific mutagenesis was carried out by inverse PCR using native pEASY-E2-recr as a template and a pair of primers Y54F F1 (5'-TACACCTTCGGCCTTCCTCTCACGC-3') and Y54F 
R1 (5'-AAGGCCGAAGGTGTACTGCTCCTCG-3') under conditions as follows: denaturation, $95^{\circ} \mathrm{C}$ for $2 \mathrm{~min}$; 30 cycles of $95^{\circ} \mathrm{C}$ for $20 \mathrm{~s}, 68^{\circ} \mathrm{C}$ for $20 \mathrm{~s}$, and $72{ }^{\circ} \mathrm{C}$ for $3 \mathrm{~min}$; and the final extension, $72{ }^{\circ} \mathrm{C}$ for $8 \mathrm{~min}$. The PCR product was digested at $37^{\circ} \mathrm{C}$ for $2 \mathrm{~h}$ to digest the native template with the help of $D p n$ I. The digested product was directly transformed into E. coli BL21(DE3) competent cells. The positive recombinant cells were cultured at $37^{\circ} \mathrm{C}$ and $200 \mathrm{rpm}$ in LB medium with $100 \mu \mathrm{g} / \mathrm{mL}$ Amp. The recombinant cell named as E. coli Trans1-T1/pEASY-E2-recr-mut was selected by colony PCRs and the recombinant plasmid pEASY-E2-recr-mut was further extracted and verified by DNA sequencing (Sunny Biotechnology, Shanghai, China). Following the same procedure for the recombinant ReCR, the positive recombinant cell named as E. coli BL21(DE3)/pEASY-E2-recr-mut was obtained and the ReCR variant $\mathrm{Y} 54 \mathrm{~F}$ was purified for further characterization including kinetic parameters and catalytic performance in NBPO reduction.

The homology model of ReCR was built on the X-ray crystallographic structures of ADH-A from Rhodococcus ruber (PDB: 2XAA, resolution of $2.8 \AA$ ) by HHpred server [37]. Water molecules, ligands, and other hetero atoms (except the $\mathrm{NAD}^{+}$coenzyme and the zinc ion) were removed from the protein molecule. The coenzyme was remodeled as NADH. The charge of the catalytic zinc ion was assigned to +2 , and the ligating side chain of Cys 38 was set as deprotonated and negatively charged. For the homology model of ReCR Y54F, the substitution of Tyr54 to Phe was introduced by FoldX [38]. A structure energy minimization of the proteins was performed to remove improper torsions of the side-chain conformation and correct the covalent geometry. The ligand molecule structures (NBPO and NADH) were directly drawn in ChemBioDraw and followed by an energy minimization. Global docking was performed using AutoDock Vina under the default docking parameters [39]. Point charges were initially assigned according to the AMBER03 force field [40], and then damped to mimic the less polar Gasteiger charges. Subsequently, local docking was executed to predict the binding energy and fine-tune the ligand placement in the binding site.

\subsection{Nucleotide Sequence Accession Number}

The nucleotide sequence of ReCR has been submitted to the GenBank database under the accession number of KX827723.

\section{Conclusions}

The enzyme ReCR showed high specific activity, moderate thermostability, and strict (S)-stereoselectivity for asymmetric bioreduction of NBPO to (S)-NBHP. The NAD(H)-specific enzyme was active over broad $\mathrm{pH}$ and temperature ranges, and tolerated a higher concentration of organic solvents, offering greater flexibility in practical biocatalysis. Particularly, the reduction of NBPO to $(S)$-NBHP was irreversible, which was kinetically in favor of both coenzyme regeneration and formation of (S)-NBHP. The substitution of Tyr54 to Phe further improved the catalytic efficiency of ReCR including kinetic parameters and the productivity of (S)-NBHP. The $k_{\text {cat }} / K_{\mathrm{m}}$ values of ReCR Y54F for NBPO $\left(49.17 \mathrm{~s}^{-1} \mathrm{mM}^{-1}\right),(R / S)$-2-octanol (56.56 s $\left.\mathrm{s}^{-1} \mathrm{mM}^{-1}\right)$, and 2-propanol $\left(20.69 \mathrm{~s}^{-1} \mathrm{mM}^{-1}\right)$ were 1.37, 4.34, and 2.12 times higher than those of ReCR $\left(35.98 \mathrm{~s}^{-1} \mathrm{mM}^{-1}, 13.04 \mathrm{~s}^{-1} \mathrm{mM}^{-1}\right.$, and $9.74 \mathrm{~s}^{-1} \mathrm{mM}^{-1}$ ), respectively. Furthermore, the (S)-NBHP yield was increased from $77.78 \%$ to $95.89 \%$ in the aqueous/(R/S)-2-octanol biphasic system when asymmetric reduction of $1.5 \mathrm{M}$ NBPO was catalyzed for $12 \mathrm{~h}$ by whole cells of E. coli overexpressing ReCR Y54F instead of ReCR. Taken as a whole, ReCR variant Y54F has a great potential in the asymmetric synthesis of (S)-NBHP using $(R / S)$-2-octanol or 2-propanol as a co-substrate.

Supplementary Materials: The following are available online at http:/ / www.mdpi.com/1420-3049/23/12/3117/ s1, Figure S1: Gas chromatograph analysis for standards $N$-Boc-3-piperidone (A), (S)-N-Boc-3-hydroxypiperidine and $(R)-N$-Boc-3-hydroxypiperidine; Figure S2: Gas chromatograph-mass spectrometry analysis of $(S)-N-B o c-3-$ hydroxypiperidine in asymmetric reduction of $\mathrm{N}$-Boc-3-piperidone; Figure S3: The Michaelis-Menten kinetics of ReCR; Figure S4. The Michaelis-Menten kinetics of ReCR variant Y54F; Table S1: Effect of metal ions, EDTA, dithiothreitol and sodium iodoacetate on the activity of recombinant ReCR. 
Author Contributions: Conceptualization, X.Y. and M.Y. (Meirong Ying); Data curation, X.Y. and M.Y. (Meilan Yu); Formal analysis, X.Y., F.C. and M.Y. (Meirong Ying); Funding acquisition, X.Y. and M.Y. (Meilan Yu); Investigation, J.Z., C.W., M.H., Y.J. and F.C.; Supervision, Z.W.; Writing - original draft, X.Y. and M.Y. (Meirong Ying).

Funding: This work was supported by the Natural Science Fundation of Zhejiang Province, China (No. LY17B020012) and the National Natural Science Fundation of China (No. 21405140).

Conflicts of Interest: The authors declare no conflict of interest.

\section{References}

1. Babu, M.S.; Raghunadh, A.; Ramulu, K.; Dahanukar, V.H.; Kumar, U.K.S.; Dubey, P.K. A practical and enantiospecific synthesis of (-)-(R)- and (+)-(S)-piperidin-3-ols. Helv. Chim. Acta 2014, 97, 1507-1515. [CrossRef]

2. Vitaku, E.; Smith, D.T.; Njardarson, J.T. Analysis of the structural diversity, substitution patterns, and frequency of nitrogen heterocycles among U.S. FDA approved pharmaceuticals. J. Med. Chem. 2014, 57, 10257-10274. [CrossRef] [PubMed]

3. Chen, L.-F.; Zhang, Y.-P.; Fan, H.-Y.; Wu, K.; Lin, J.-P.; Wang, H.-L.; Wei, D.-Z. Efficient bioreductive production of (R)-N-Boc-3-hydroxypiperidine by a carbonyl reductase. Catal. Commun. 2017, 97, 5-9. [CrossRef]

4. Ju, X.; Tang, Y.; Liang, X.; Hou, M.; Wan, Z.; Tao, J. Development of a biocatalytic process to prepare (S)-N-Boc-3-hydroxypiperidine. Org. Process Res. Dev. 2014, 18, 827-830. [CrossRef]

5. Amat, M.; Llor, N.; Huguet, M.; Molins, E.; Espinosa, E.; Bosch, J. Unprecedented oxidation of a phenylglycinol-derived 2-pyridone: Enantioselective synthesis of polyhydroxypiperidines. Org. Lett. 2001, 3, 3257-3260. [CrossRef] [PubMed]

6. Zhang, Y.-J.; Zhang, W.-X.; Zheng, G.-W.; Xu, J.-H. Identification of an $\varepsilon$-keto ester reductase for the efficient synthesis of an (R)- $\alpha$-lipoic acid precursor. Adv. Synth. Catal. 2015, 357, 1697-1702. [CrossRef]

7. Lacheretz, R.; Pardo, D.G.; Cossy, J. Daucus carota mediated-reduction of cyclic 3-oxo-amines. Org. Lett. 2009, 11, 1245-1248. [CrossRef] [PubMed]

8. Chen, L.-F.; Fan, H.-Y.; Zhang, Y.-P.; Wu, K.; Wang, H.-L.; Lin, J.-P.; Wei, D.-Z. Development of a practical biocatalytic process for (S)-N-Boc-3-hydroxypiperidine synthesis. Tetrahedron Lett. 2017, 58, 1644-1650. [CrossRef]

9. Xu, G.-P.; Wang, H.-B.; Wu, Z.-L. Efficient bioreductive production of (S)-N-Boc-3-hydroxypiperidine using ketoreductase ChKRED03. Proc. Biochem. 2016, 51, 881-885. [CrossRef]

10. Hummel, W.; Groger, H. Strategies for regeneration of nicotinamide coenzymes emphasizing self-sufficient closed-loop recycling systems. J. Biotechnol. 2014, 191, 22-31. [CrossRef] [PubMed]

11. Stamper, W.; Kosjek, B.; Faber, K.; Kroutil, W. Biocatalytic asymmetric hydrogen transfer employing Rhodococcus ruber DSM 44541. J. Org. Chem. 2003, 68, 402-406. [CrossRef] [PubMed]

12. Huang, L.; Ma, H.-M.; Yu, H.-L.; Xu, J.-H. Altering the substrate specificity of reductase CgKR1 from Candida glabrata by protein engineering for bioreduction of aromatic $\alpha$-keto esters. Adv. Synth. Catal. 2014, 356, 1943-1948. [CrossRef]

13. Turner, N.J.; O’Reilly, E. Biocatalytic retrosynthesis. Nat. Chem. Biol. 2013, 9, 285-288. [CrossRef] [PubMed]

14. Itoh, N.; Isotani, K.; Nakamura, M.; Inoue, K.; Isogai, Y.; Makino, Y. Efficient synthesis of optically pure alcohols by asymmetric hydrogen-transfer biocatalysis: Application of engineered enzymes in a 2-propanol-water medium. Appl. Microbiol. Biotechnol. 2012, 93, 1075-1085. [CrossRef] [PubMed]

15. Makino, Y.; Inoue, K.; Dairi, T.; Itoh, N. Engineering of phenylacetaldehyde reductase for efficient substrate conversion in concentrated 2-propanol. Appl. Environ. Microbiol. 2005, 71, 4713-4720. [CrossRef] [PubMed]

16. Au, S.K.; Bommarius, B.R.; Bommarius, A.S. Biphasic reaction system allows for conversion of hydrophobic substrates by amine dehydrogenases. ACS Catal. 2014, 4, 4021-4026. [CrossRef]

17. De Gonzalo, G.; Lavandera, I.; Faber, K.; Kroutil, W. Enzymatic reduction of ketones in "micro-aqueous" media catalyzed by ADH-A from Rhodococcus ruber. Org. Lett. 2007, 9, 2163-2166. [CrossRef] [PubMed]

18. Itoh, N.; Matsuda, M.; Mabuchi, M.; Dairi, T.; Wang, J. Chiral alcohol production by NADH-dependent phenylacetaldehyde reductase coupled with in situ regeneration of NADH. Eur. J. Biochem. 2002, 269, 2394-2402. [CrossRef] [PubMed]

19. Xu, G.-C.; Tang, M.-H.; Ni, Y. Asymmetric synthesis of lipitor chiral intermediate using a robust carbonyl reductase at high substrate to catalyst ratio. J. Mol. Catal. B: Enzym. 2016, 123, 67-72. [CrossRef] 
20. Chen, X.; Liu, Z.-Q.; Lin, C.-P.; Zheng, Y.-G. Efficient biosynthesis of ethyl (R)-4-chloro- 3-hydroxybutyrate using a stereoselective carbonyl reductase from Burkholderia gladioli. BMC Biotechnol. 2016, 16, 70. [CrossRef] [PubMed]

21. Nealon, C.M.; Musa, M.M.; Patel, J.M.; Phillips, R.S. Controlling substrate specificity and stereospecificity of alcohol dehydrogenases. ACS Catal. 2015, 5, 2100-2114. [CrossRef]

22. Stepankova, V.; Bidmanova, S.; Koudelakova, T.; Prokop, Z.; Chaloupkova, R.; Damborsky, J. Strategies for stabilization of enzymes in organic solvents. ACS Catal. 2013, 3, 2823-2836. [CrossRef]

23. Wang, Z.; Song, Q.; Yu, M.; Wang, Y.; Xiong, B.; Zhang, Y.; Zheng, J.; Ying, X. Characterization of a stereospecific acetoin(diacetyl) reductase from Rhodococcus erythropolis WZ010 and its application for the synthesis of (2S,3S)-2,3-butanediol. Appl. Microbiol. Biotechnol. 2014, 98, 641-650. [CrossRef] [PubMed]

24. Yu, M.; Huang, M.; Song, Q.; Shao, J.; Ying, X. Characterization of a (2R,3R)-2,3-butanediol dehydrogenase from Rhodococcus erythropolis WZ010. Molecules 2015, 20, 7156-7173. [CrossRef] [PubMed]

25. Abokitse, K.; Hummel, W. Cloning, sequence analysis, and heterologous expression of the gene encoding a (S)-specific alcohol dehydrogenase from Rhodococcus erythropolis DSM 43297. Appl. Microbiol. Biotechnol. 2003, 62, 380-386. [CrossRef] [PubMed]

26. Itoh, N.; Morihama, R.; Wang, J.; Okada, K.; Mizuguchi, N. Purification and characterization of phenylacetaldehyde reductase from a styrene-assimilating Corynebacterium strain, ST-10. Appl. Environ. Microbiol. 1997, 63, 3783-3788. [PubMed]

27. Kasprzak, J.; Bischoff, F.; Rauter, M.; Becher, K.; Baronian, K.; Bode, R.; Schauer, F.; Vorbrodt, H.-M.; Kunze, G. Synthesis of 1-(S)-phenylethanol and ethyl (R)-4-chloro-3-hydroxybutanoate using recombinant Rhodococcus erythropolis alcohol dehydrogenase produced by two yeast species. Biochem. Eng. J. 2016, 106, 107-117. [CrossRef]

28. Makino, Y.; Dairi, T.; Itoh, N. Engineering the phenylacetaldehyde reductase mutant for improved substrate conversion in the presence of concentrated 2-propanol. Appl. Microbiol. Biotechnol. 2007, 77, 833-843. [CrossRef] [PubMed]

29. Karabec, M.; Łyskowski, A.; Tauber, K.C.; Steinkellner, G.; Kroutil, W.; Grogan, G.; Gruber, K. Structural insights into substrate specificity and solvent tolerance in alcohol dehydrogenase ADH-A from Rhodococcus ruber DSM 44541. Chem. Commun. 2010, 46, 6314-6316. [CrossRef] [PubMed]

30. Ying, X.; Wang, Y.; Xiong, B.; Wu, T.; Xie, L.; Yu, M.; Wang, Z. Characterization of an allylic/benzyl alcohol dehydrogenase from Yokenella sp. strain WZY002, an organism potentially useful for the synthesis of

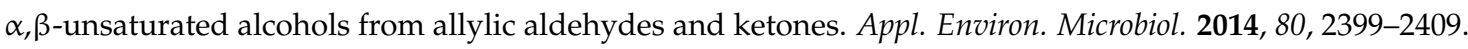
[CrossRef] [PubMed]

31. Martinez-Rojas, E.; Kurt, T.; Schmidt, U.; Meyer, V.; Garbe, L.-A. A bifunctional enzyme from Rhodococcus erythropolis exhibiting secondary alcohol dehydrogenase-catalase activities. Appl. Microbiol. Biotechnol. 2014, 98, 9249-9258. [CrossRef] [PubMed]

32. Kratzer, R.; Woodley, J.M.; Nidetzky, B. Rules for biocatalyst and reaction engineering to implement effective, NAD(P)H-dependent, whole cell bioreductions. Biotechnol. Adv. 2015, 33, 1641-1652. [CrossRef] [PubMed]

33. Glonke, S.; Sadowski, G.; Brandenbusch, C. Applied catastrophic phase inversion: A continuous non-centrifugal phase separation step in biphasic whole-cell biocatalysis. J. Ind. Microbiol. Biotechnol. 2016, 43, 1527-1535. [CrossRef] [PubMed]

34. Wei, L.; Zhang, M.; Zhang, X.; Xin, H.; Yang, H. Pickering emulsion as an efficient platform for enzymatic reactions without stirring. ACS Sustain. Chem. Eng. 2016, 4, 6838-6843. [CrossRef]

35. Yang, C.; Ying, X.; Yu, M.; Zhang, Y.; Xiong, B.; Song, Q.; Wang, Z. Towards the discovery of alcohol dehydrogenases: $\mathrm{NAD}(\mathrm{P}) \mathrm{H}$ fluorescence-based screening and characterization of the newly isolated Rhodococcus erythropolis WZ010 in the preparation of chiral aryl secondary alcohols. J. Ind. Microbiol. Biotechnol. 2012, 39, 1431-1443. [CrossRef] [PubMed]

36. Laemmli, U.K. Cleavage of structural proteins during the assembly of the head of bacteriophage T4. Nature 1970, 227, 680-685. [CrossRef] [PubMed]

37. Söding, J.; Biegert, A.; Lupas, A.N. The HHpred interactive server for protein homology detection and structure prediction. Nucleic Acids Res. 2005, 33, W244-W248. [CrossRef] [PubMed]

38. Schymkowitz, J.; Borg, J.; Stricher, F.; Nys, R.; Rousseau, F.; Serrano, L. The FoldX web server: An online force field. Nucleic Acids Res. 2005, 33, W382-W388. [CrossRef] [PubMed] 
39. Trott, O.; Olson, A.J. AutoDock Vina: Improving the speed and accuracy of docking with a new scoring function, efficient optimization, and multithreading. J. Comput. Chem. 2010, 31, 455-461. [CrossRef] [PubMed]

40. Duan, Y.; Wu, C.; Chowdhury, S.; Lee, M.C.; Xiong, G.; Zhang, W.; Yang, R.; Cieplak, P.; Luo, R.; Lee, T.; et al. A point-charge force field for molecular mechanics simulations of proteins based on condensed-phase quantum mechanical calculations. J. Comput. Chem. 2003, 24, 1999-2012. [CrossRef] [PubMed]

Sample Availability: Samples of the compounds are not available from the authors.

(C) 2018 by the authors. Licensee MDPI, Basel, Switzerland. This article is an open access article distributed under the terms and conditions of the Creative Commons Attribution (CC BY) license (http://creativecommons.org/licenses/by/4.0/). 